\title{
UPAYA MENINGKATKAN KESEHATAN IBU DAN ANAK MELALUI PROGRAM LITERASI KESEHATAN DAN HIBAH BUKU DI DESA CINTAMULYA RW 05 JATINANGOR
}

\author{
Fitri Perdana ${ }^{1}$ dan Heti Herawati ${ }^{2}$ \\ ${ }^{1}$ Dosen Pada Program Studi Ilmu Perpustakaan Fikom Unpad \\ ${ }^{2}$ Dosen Pada Fakultas Perikanan dan Ilmu Kelautan Unpad \\ E-mail: fitri.perdana@unpad.ac.id,h.herawati@unpad.ac.id
}

\begin{abstract}
ABSTRAK. Pada umumnya, seorang perempuan khususnya ibu, memegang peranan yang sangat penting dalam kesehatan keluarga. Hal ini terjadi karena seorang ibu cenderung memiliki perhatian yang lebih besar terhadap kondisi kesehatan keluarganya. Perhatian ibu sangat beragam mulai dari menerapkan gaya hidup sehat, menyediakan bahan makanan yang sehat dan segar, memasak makanan yang bergizi, mencuci pakaian, membersihkan rumah dan banyak hal lainnya yang selalu dikerjakan oleh seorang ibu. Terutama hal yang berkaitan dengan kegiatan kerja domestik keluarga. Dengan begitu banyaknya tanggung jawab dan kegiatan seorang ibu untuk menjaga kesehatan keluarga, terkadang membuatnya lupa akan kesehatannya sendiri. Padahal kesehatan seorang ibu sangatlah penting dalam menjaga dan meningkatkan kualitas kesehatan keluarga. Tujuan Pengabdian Pada Masyarakat Olahraga Kesenian dan Kreatifitas ini adalah untuk memberikan kesadaran dan informasi mengenai pentingnya menjaga kesehatan bagi ibu dan anak sehingga bisa meningkatkan aspek pembangunan, terutama dalam hal kesehatan.. Metode yang dilakukan adalah Kualitatif melalui pengamatan, observasi, wawancara, studi kepustakaan dan trianggulasi data. Hasilnya, berdasarkan hasil observasi, pemetaan wilayah dan wawancara menunjukan adanya kebutuhan masyarakat terkait literasi kesehatan bagi ibu dan anak. Untuk itu dilaksanakanlah Program penyuluhan bagaimana menjaga kesehatan bagi ibu dan anak dengan pemateri seorang ahli di bidang kesehatan, serta diadakan program hibah buku agar para ibu senantiasa bisa terus memperbaharui pengetahuan yang berkaitan dengan kesehatan dari buku-buku tersebut, dan juga buku cerita untuk anak-anak, sebagai upaya menumbuhkan minat baca anak-anak desa Cintamulya sedari kecil. Karena minat baca itu harus diawali sejak kecil. Kesimpulannya, bahwa dengan diadakan program literasi kesehatan ini, mulai membuka kesadaran dan menambah informasi akan pentingnya menjaga kesehatan, "melek" akan kesehatan.
\end{abstract}

Kata Kunci: Literasi, Kesehatan, Posyandu, Hibah Buku, Cintamulya.

\section{AN EFFORTS TO IMPROVE MOTHER AND CHILD HEALTH THROUGH HEALTH LITERATION PROGRAMS AND GRANTS BOOKS IN CINTAMULYA VILLAGE, JATINANGOR DISTRICT, SUMEDANG DISTRICT}

\begin{abstract}
Woman, especially a mother, plays a very important role in family health. This happens because a mother tends to have greater attention to her family's health condition. Mother's concerns range from adopting a healthy lifestyle, providing healthy and fresh food, cooking nutritious food, washing clothes, cleaning the house and many other things that a mother always does. Especially with regard to family domestic work activities. With so many responsibilities and activities a mother to maintain family health, sometimes make him forget his own health. Though the health of a mother is very important in maintaining and improving the quality of family health. The Purpose of Dedication to the Sports Society of Arts and Creativity is to provide awareness and information on the importance of maintaining health for mothers and children so as to improve aspects of development, especially in terms of health. Methods conducted are qualitative: observation, observation, interview, literature study and triangulation data. The result, based on the results of observation, area mapping and interviews indicate the existence of community needs related health literacy for mother and child. For this purpose, a program of extension is conducted on how to maintain the health of mothers and children with the speakers of a health expert, and books grant program is held so that mothers can continue to update the health-related knowledge of the books as well as storybooks for children, children, in an effort to foster interest in reading the children of Cintamulya village from childhood. Because the interest of reading that must be started since childhood. In conclusion, that with this health literacy program, began to open awareness and add information about the importance of maintaining health, "health literacy".
\end{abstract}

Keywords: Literacy, Health, Posyandu, Books Grant, Cintamulya

\section{PENDAHULUAN}

Pada era informasi sekarang ini, Indonesia sedang giat-giatnya melaksanakan pembangunan disegala bidang. Adapun tujuan pembangunan di negara kita, seperti yang dipaparkan oleh Dian Sinaga (2005:9), yaitu diarahkan untuk mewujudkan masyarakat adil dan makmur yang merata material dan spiritualnya berdasarkan landasan Idiil Pancasila dan Landasan Konstitusional Undang-undang Dasar 1945. Hal ini misalnya dituangkan dalam Garis-Garis Besar Haluan Negara 1978: "Pembangunan nasional bertujuan untuk mewujudkan suatu masyarakat adil dan makmur yang merata material dan spiritualnya berdasarkan pancasila dalam wadah negara kesatuan Republik Indonesia yang merdeka". Salah satu aspek yang turut menunjang lajunya pembangunan tersebut adalah bidang kesehatan. Berdasarkan rumusan dari Biro Komunikasi dan Pelayanan Masyarakat Sekretariat Jenderal Kementerian Kesehatan RI (2017): "Pembangunan kesehatan adalah 
investasi utama bagi pembangunan sumber daya manusia Indonesia. Pembangunan kesehatan pada dasarnya adalah upaya untuk meningkatkan kesadaran, kemauan, serta kemampuan setiap orang untuk dapat berperilaku hidup yang sehat untuk mencapai derajat kesehatan masyarakat yang setinggi-tingginya.Untuk mewujudkan hal tersebut, perlu perencanaan pembangunan kesehatan yang sistematis, terarah, terpadu dan menyeluruh, serta dibutuhkan keterlibatan berbagai sektor dan seluruh komponen bangsa dalam pelaksanaannya.".

Melancarkan program pembangunan kesehatan tersebut, tentu saja diawali dari keluarga yang sehat. Hal ini sesuai dengan apa yang dikemukakan oleh Presiden Joko Widodo dalam pidatonya dalam Konferensi Internasional Keluarga Berencana (International Conference on Family Planning/ICFP) di Nusa Dua, Bali 25 Januari 2016 menegaskan bahwa generasi yang berkualitas, yang berkarakter, yang berbudi pekerti luhur, yang cinta sesama manusia hanya dapat dilahirkan oleh ibu yang sehat, anak yang sehat dan berasal dari keluarga yang sehat dan sejahtera. Keluarga yang sehat merupakan keluarga yang optimal dimana setiap anggota keluarganya berada dalam kondisi sehat baik sehat jasmani, sehat rohani, dan sosial.

Pada umumnya, seorang perempuan khususnya seorang ibu, memegang peranan yang sangat penting dalam keluarga. Hal ini terjadi karena seorang ibu cenderung memiliki perhatian yang lebih besar terhadap kondisi kesehatan keluarganya. Perhatian ibu sangatlah beragam, mulai dari menerapkan gaya hidup sehat, menyediakan bahan makanan yang sehat dan segar, memasak makanan yang bergizi, mencuci pakaian, membersihkan rumah dan banyak hal lainnya yang selalu dikerjakan oleh seorang ibu. Terutama hal yang berkaitan dengan kegiatan kerja domestik keluarga. Dengan begitu banyaknya tanggung jawab dan kegiatan seorang ibu untuk menjaga kesehatan keluarga, terkadang membuatnya lupa akan kesehatannya sendiri. Padahal kesehatan seorang ibu sangatlah penting dalam menjaga dan meningkatkan kualitas kesehatan keluarganya.

Desa Cintamulya merupakan salah satu desa yang berada di Jatinangor, Kab. Sumedang. Desa ini cukup berkembang, posisinya terletak di belakang salah satu Pabrik di daerah Rancaekek. Di Desa Cintamulya ini sebagian besar wanitanya adalah bekerja sebagai buruh pabrik dan sebagian lagi sebagai ibu rumah tangga. Jika melihat kondisi ini, terlihat dari hasil pengamatan dan wawancara analisis desa, kurangnya kesadaran masyarakat terutama seorang ibu akan pentingnya kesehatan bagi ibu dan anak. Berdasarkan hasil observasi dan pemetaan wilayah tersebut menunjukan adanya kebutuhan masyarakat terkait literasi kesehatan bagi ibu dan anak. Merujuk pada kondisi tersebut, di Desa Cintamulya khususnya pada RW 05, kami bermaksud menindaklanjuti permasalahan yang ada, dengan akan dilaksanakannya program kegiatan Pengabdian Pada
Masyarakat Prioritas pada tahun 2017 ini (PPM OKK). Kegiatan akan diarahkan pada peningkatan literasi kesehatan bagi ibu dan anak serta hibah buku di RW 05 Desa Cintamulya. Harapannya adalah kegiatan pengabdian ini dapat memberikan pengetahuan dan keterampilan kepada khalayak sasaran tersebut, mengenai pentingnya menjaga kesehatan ibu dan anak, kampanye gemar makan-makanan sehat dan bernutrisi, serta dapat merubah pola dan perilaku masyarakat untuk dapat meningkatkan kesadaran akan pentingnya kesehatan, gizi dan nutrisi bagi ibu dan anak. Desa Cintamulya jika dilihat dari apek georafis Sebagai berikut:

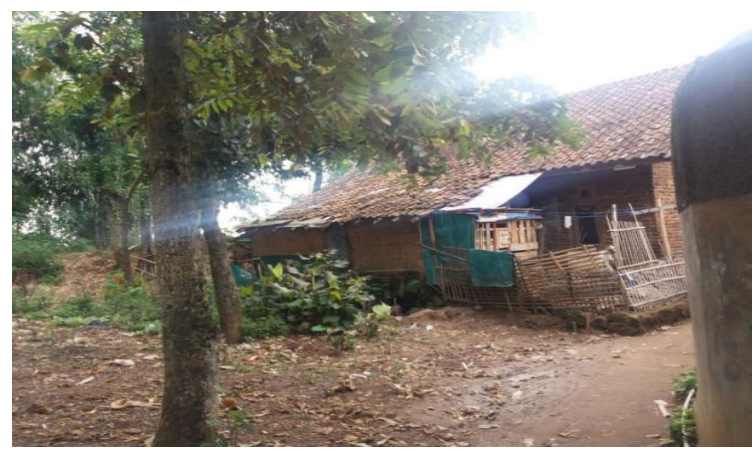

Gambar 1. Lingkungan Di RW 05 Cintamulya

Menurut Undang-undang No. 23 tahun 1992 pasal 22 menyatakan bahwa kesehatan lingkungan diselenggarakan untuk mewujudkan kualitas lingkungan yang sehat yaitu keadaan lingkungan yang bebas dari resiko yang membahayakan kesehatan dan keselamatan manusia (Marsaulina, 2004: 2). Hal ini yang menjadi salah satu latar belakang mengapa kami memutuskan mangadakan kegiatan PPM OKK yang berkaitan dengan literasi kesehatan. Dan dari kegiatan PKM OKK ini pun dapat menanamkan sejak usia dini kepada anakanak yang tinggal di desa tentang pentingnya menjaga kebersihan dan kesehatan. Kesimpulan pembahasan di atas, yaitu sangat diperlukannya pemahaman kesehatan dan kebersihan lingkungan.

\section{METODE}

Metode yang digunakan adalah metode kualitatif. Nasution (1995:5) mengatakan bahwa penelitian kualitatif pada hakikatnya adalah mengamati orang dalam hidupnya, berinteraksi dengan mereka, berusaha memahami bahasa dan tafsiran mereka tentang dunia sekitarnya. Untuk itu, peneliti harus terjun ke lapangan dalam waktu yang cukup. Lebih jauh menurut Nasution, kualitatif disebut juga naturalistik. Disebut naturalistik karena situasi lapangan penelitian bersifat "natural" atau wajar sebagaimana adanya, tanpa manipulasi ataupun diatur dengan eksperimen maupun test yang bertujuan untuk mendapatkan gambaran yang seutuhnya (mendalam dan kontekstual) mengenai suatu hal menurut pandangan manusia. Metode kualitatif berhubungan dengan ide, persepsi, pendapat, kepercayaan orang yang 
diteliti tentang suatu topik. Data-data tersebut berupa data yang diperoleh dan dikumpulkan melalui beberapa teknik: Observasi, wawancara, studi kepustakaan atau dokumenter dan trianggulasi data. Teknik analisis data yang digunakan dalam penelitian ini ialah seperti yang dikemukakan oleh Nasution, yaitu: Reduksi data, tampilan data, mengambil keputusan dan verifikasi. Kami melakukan wawancara dengan pihak-pihak terkait seperti: Kepala Desa, RT, RW, Ibu-Ibu PKK, Kader Posyandu dan Masyarakat.

\section{HASIL DAN PEMBAHASAN}

Menurut pengertiannya sendiri, pemahaman kesehatan dan kebersihan lingkungan adalah kemampuan seseorang untuk mengerti atau memahami untuk menciptakan lingkungan yang sehat, aman, bersih, dan sejuk sehingga tidak mudah terserang dari berbagai penyakit. Dari pengertian tersebut warga Desa Cintamulya masih harus menumbuhkan dan meningkatkan pola pikir yang dapat membawa ke arah yang lebih baik. Program PPM OKK yang ditujukan kepada masyarakat Desa Cintamulya perihal literasi kesehatan diharapkan dapat membantu meningkatkan kondisi dan pola hidup yang lebih sehat, guna para ibu dan anak di sekitar. Metode yang digunakan dalam kegiatan PPM OKK adalah dengan melakukan kegiatan penyuluhan/pelatihan yang diawali terlebih dahulu dengan pemberian materi, kemudian diskusi, dan praktik atau simulasi. Kegiatan pelatihan dipandu oleh narasumber (tenaga ahli) sebagai fasilitator pelatihan dan dibantu dengan seperangkat alat untuk melakukan simulasi atau praktik secara langsung. Acara PPM OKK ini dilaksanakan pada hari Sabtu, 21 Oktober 2017 dan dibuka langsung oleh Ibu Kepala Desa, Ibu Lilis.

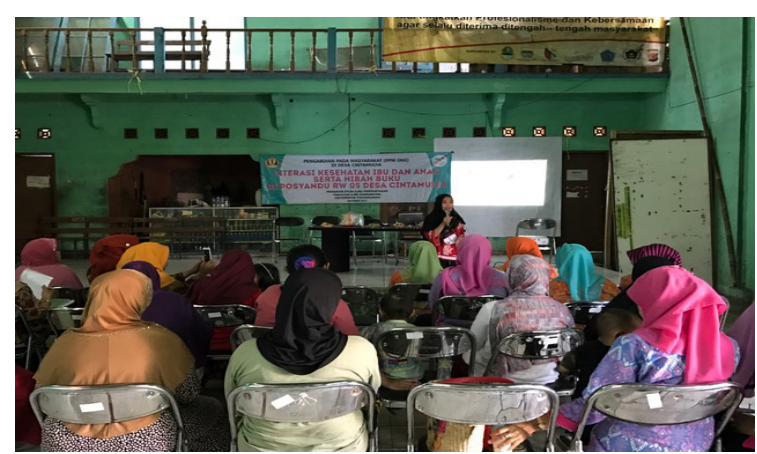

Gambar 2. Pembukaan PPM OKK Oleh Ibu Kepala Desa

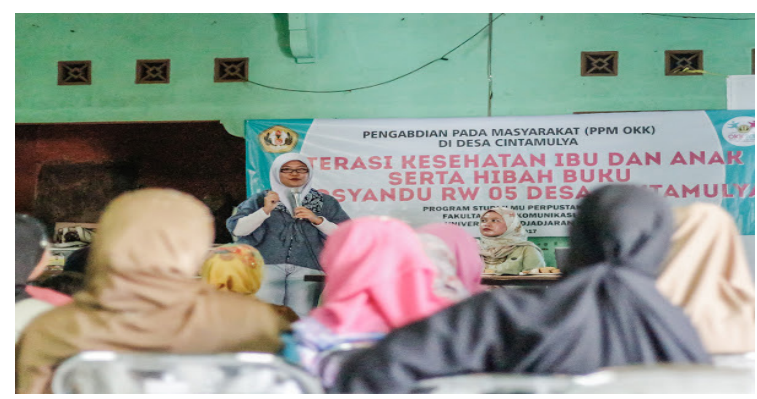

Gambar 3. Penyampaian Materi Kesehatan Oleh Ibu Sefita Aryuti Nirmala, SST., M.Keb.
Pemateri yang berkaitan dengan kesehatan adalah ahli dibidangnya, salah satu dosen Fakultas Kedokteran, Prodi Kebidanan Yaitu: Sefita Aryuti Nirmala, SST., M.Keb. Beliau memaparkan tentang: Pentingnya Kesehatan Ibu dan Anak.

Bahwa Pembangunan kesehatan Sebagai upaya pemerintah untuk meningkatkan kesadaran, kemauan, serta kemampuan setiap orang untuk berperilaku hidup yang sehat. Kemauan tersebut dimulai dari keluarga yang sehat. Keluarga sehat merupakan keluarga yang setiap anggota keluarganya berada dalam kondisi sehat jasmani, rohani, dan sosial. Peran ibu dalam menciptakan keluarga sehat mulai dari menerapkan gaya hidup sehat, menyediakan makanan yang sehat dan bergizi, menjaga kebersihan rumah dan lingkungan, menciptakan harmonisasi kehidupan keluarga. Untuk menjaga keberlangsungan keluarga sehat, seorang ibu dituntut harus selalu menjaga kesehatan dirinya. Terdapat 12 Indikator Keluarga sehat, yakni:

1. Lima indikator dalam gizi, kesehatan ibu dan anak:

1) Keluarga mengerti program keluarga berencana (KB).

2) Ibu hamil memeriksa kehamilannya sesuai standar.

3) Balita mendapatkan imunisasi lengkap.

4) Pemberian ASI Ekslusif 0-6 bulan.

5) Pemantauan pertumbuhan balita.

2. Dua Indikator dalam pengendalian penyakit menular dan tidak menular:

6) . Penderita hipertensi berobat teratur.

7) . Penderita TB Paru berobat sesuai standar.

3. Dua Indikator dalam perilaku sehat

8). Tidak adanya anggota keluarga yang merokok.

9). Sekeluarga sudah menjadi anggota JKN.

\section{Dua indikator terkait lingkungan sehat}

10). Mempunyai sarana air bersih.

11). Menggunakan jamban keluarga.

\section{Satu Indikator kesehatan jiwa}

12) Anggota keluarga akses dalam pelayanan kesehatan jiwa.

Berkaitan dengan literasi kesehatan, kami juga memberikan beberapa tips mengukur lingkar perut ideal dan juga pemberian games senam otak, sebagai berikut:

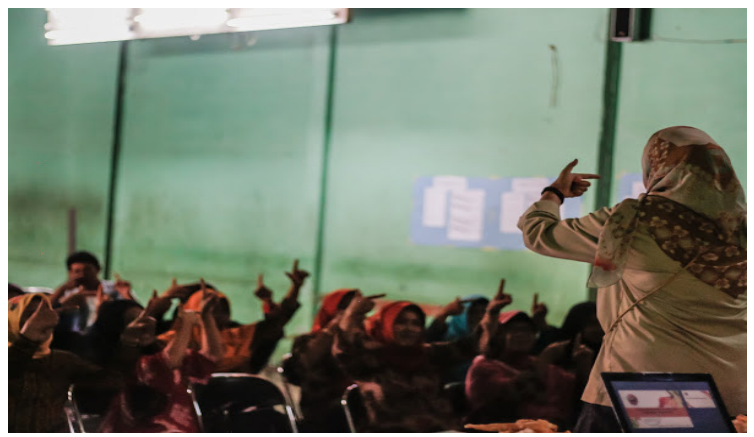

Gambar 4. Simulasi Senam Otak 
Selain menjaga kesehatan ibu, tumbuh kembang dan kesehatan anak juga perlu dilakukan. Karena hal ini berkaitan dengan tumbuh kembang otak anak. Sejak kehamilan 6 bulan sampai umur 2 tahun merupakan masa yang sangat penting. Maka bayi membutuhkan banyak protein, karbohidrat dan lemak, sampai berumur 1 tahun. Pemberian nutrisi yang tepat sangatlah dianjurkan, seperti: Ikan, daging, telur, buah-buahan, sayuran, susu, dll. Berkaitan dengan kesehatan, kami juga membuka sessi diskusi dan tanya jawab dan animo masyarakat luar biasa:

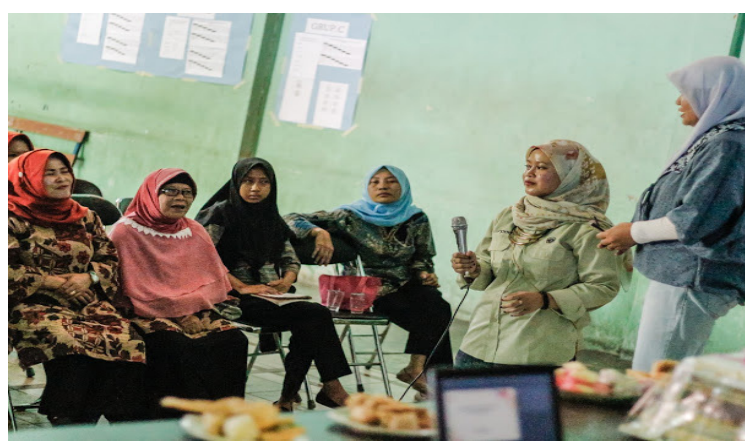

Gambar 5. Sessi Diskusi Dan Tanya Jawab

Informasi selain dari pemaparan pakar/ahli, ada pula sumber informasi lainnya yaitu: buku. Buku merupakan salah satu sumber informasi. Untuk itu, berkaitan dengan literasi Kesehatan, dalam PPM OKK ini juga Tim bermaksud menghibahkan buku-buku yang berkaitan dengan kesehatan agar para ibu senantiasa bisa terus memperbaharui pengetahuan yang berkaitan dengan kesehatan dari buku-buku tersebut, dan juga buku cerita untuk anak-anak, hal ini dilakukan sebagai upaya menumbuhkan minat baca anak-anak desa Cintamulya sedari kecil. Karena minat baca itu harus diawali sejak dini. Membaca merupakan salah satu upaya yang sangat penting dalam mendukung proses belajar mengajar. Membaca merupakan salah satu langkah yang sangat menentukan berhasil atau tidaknya proses belajarmengajar yang diharapkan. Dengan membaca berarti kita menterjemahkan, menginterpretasikan tanda-tanda atau lambang-lambang dalam bahasa yang dipahami oleh pembaca (Sinaga, 2004:87). Konsep pendidikan yang dianut di negara kita adalah konsep pendidikan sepanjang hayat (life long learning). Hal ini sejalan dengan kewajiban setiap insan untuk selalu belajar sejak dilahirkan sampai akhir hayatnya. Kepandaian dan kemampuan membaca merupakan faktor yang amat penting dalam proses belajar. Menurut pengalaman, pemecahan berbagai persoalan yang berkaitan dengan ilmu dan pengetahuan berkorelasi sangat erat dalam kegiatan membaca. Topandi H. Ismail (1982:25) Dalam Sinaga (2004:88) menyatakan, "Karena dengan membaca kita akan memperoleh sejumlah ilmu pengetahuan dan keterampilan yang berguna bagi kehidupan. Membaca laksana ilmu pengetahuan." Membaca merupakan kebutuhan pokok bagi manusia. Kalau kita perhatikan para tokoh, yang bertaraf nasional ataupun internasional dalam berbagai bidang, sebagaimana lahir dan besar karena kemampuannya dalam bidang membaca. Mereka belajar secara otodidak atau self study dalam berbagai disiplin ilmu pengetahuan, namun kemudian bisa mengubah kehidupan suatu bangsa bahkan dunia. Peran perpustakaan sekolah dalam pembinaan minat baca sangat penting, seperti yang dikemukakan oleh Mulyani Achmad N. Pada Bulletin Perpustakaan UII nomor 8-9 Desember/Januari (1978:5-6) Dalam Sinaga (2004:95) sebagai berikut:

1. Menimbukan kecintaan terhadap membaca, memupuk kesadaran membaca, dan menanamkan reading habit.

2. Membimbing dan mengarahkan teknik memahami bacaan.

3. Memperluas horison pengetahuan dan memperdalam pengetahuan yang sudah diperoleh.

4. Membantu perkembangan kecakapan bahasa dan daya pikir dengan menyajikan buku-buku yang bermutu.

5. Memberikan dasar-dasar ke arah studi mandiri.

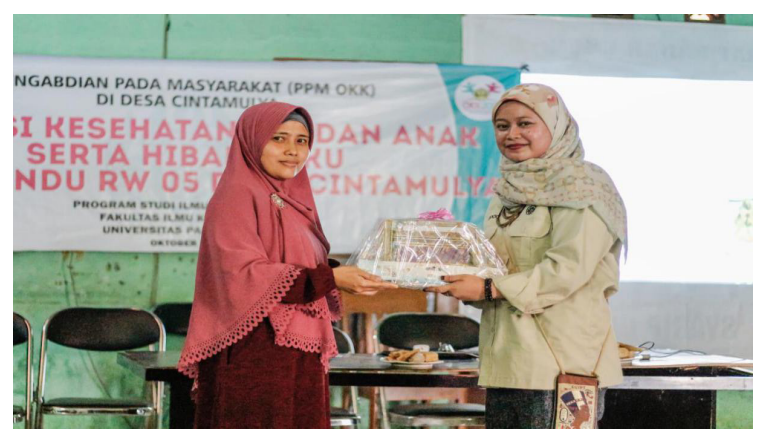

Gambar 6. Simbolis Serah Terima Hibah Buku PPM OKK Cintamulya 05

Menurut Sutarno (2004:229) Minat dan budaya masyarakat harus dilakukan dengan beberapa cara, seperti:

1. Mulai sejak anak usia dini. Jika kita menginginkan anak-anak kita senang terhadap buku bacaan, maka kita harus menyediakannya dan membimbingnya secara teratur. Jika kegemaran dan kebiasaan itu telah terbentuk pada jiwa anak-anak, maka usianya yang bertambah, keinginannya juga makin bertambah, selanjutnya perlu penyediaan bahan bacaan yang cocok, dengan isi dan mutu serta misinya diarahkan kepada hal-hal positif.

2. Dilakukan secara terus menerus. Jadi upaya itu harus berlanjut, kontinyu dan secara teratur.

3. Bahan bacaan. Tersedianya bahan bacaan yang mencukupi, baik jumlah, jenis dan mutu.

4. Ditanamkan suatu kebiasaan.

5. Lingkungan yang mendukung. Selain lingkungan sekolah, ada peran keluarga di rumah juga dalam upaya menciptakan suasana dan kebiasaan membaca.

6. Adanya suatu kebutuhan dan tantangan (tugas, 
ujian, kelulusan, dll). Mau tidak mau, hatus belajar (membaca) jika ingin memperoleh hasil yang baik.

7. Tersedianya fasilitas dan kemudahan.

Untuk itu saya selaku Ketua PPM OKK Literasi dan Hibah buku, dalam kegiatan PPM OKK ini juga secara simbolis memberikan hibah buku, yang diserahkan pada salah satu Pengelola/Kader Posyandu RW 05 Cintamulya, yaitu: Ibu Siti Solihan.

\section{SIMPULAN}

Program PPM OKK yang ditujukan kepada masyarakat Desa Cintamulya perihal Literasi Kesehatan sebagai upaya meningkatkan kesadaran masyarakat akan pentingnya menjaga kesehatan, diharapkan dapat membantu meningkatkan kondisi dan pola hidup yang lebih sehat, guna para ibu dan anak di sekitar. Sumber informasi selain dari pemaparan pakar/ahli, ada pula sumber informasi lainnya yaitu: Buku. Buku merupakan salah satu sumber informasi. Untuk itu, berkaitan dengan literasi Kesehatan, dalam PPM OKK ini juga Tim bermaksud menghibahkan buku-buku yang berkaitan dengan kesehatan agar para ibu senantiasa bisa terus memperbaharui pengetahuan yang berkaitan dengan kesehatan dari buku-buku tersebut, dan juga buku cerita untuk anak-anak, hal ini dilakukan sebagai upaya menumbuhkan minat baca anak-anak desa Cintamulya sedari kecil. Karena minat baca itu harus diawali sejak kecil.

\section{UCAPAN TERIMA KASIH}

Kami mengucapkan banyak terimakasih kepada seluruh pihak yang terkait, yakni: Bapak Kepala Desa Cintamulya, Ibu Kepala Desa sebagai penggerak ibu- ibu PKK, Ibu-ibu PKK, Kader Posyandu, Bapak RT dan RW 05, Seluruh masyarakat desa Cintamulya, dan banyak lagi yang tidak bisa disebutkan satupersatu. Semoga kebaikannya dibalas oleh Allah SWT, Aamiin.

\section{DAFTAR PUSTAKA}

Nasution (1995). Metode Research. Jakarta: Bumi Aksara.

Sinaga, Dian. (2004). Mengelola Perpustakaan sekolah. Bandung: Bejana Ilmu.

(2005). Perpustakaan Sekolah. Bandung: Kreasi Media Utama.

12 Indikator Keluarga Sehat. http://www. kabarsehatonline.com/article/12-indikatorkeluarga-sehat

Kementerian Kesehatan Republik Indonesia. (2013). Buku Saku: Pelayanan Kesehatan Ibu di Fasilitas Kesehatan dasar dan Rujukan. Jakarta: Kementerian Kesehatan Republik Indonesia. Didownload dari http://www.searo.who.int/ indonesia/documents/976-602-235-265-5-bukusaku-pelayanan-kesehatan-ibu.pdf?ua $=1$

Metro TV News. (2016). Indikator Keluarga Sehat. Jakarta: Metro TV. Diakses dari http://video. metrotvnews.com/play/2016/04/12/512162/ indikator-keluarga-sehat,

Marsaulina (2004). Peningkatan Kualitas Terhadap Perumahan Kumuh dan Pemuniman Kumuh. Jakarta: Kementrian Pekerjaan Umum dan Perumahan Rakyat. 